\title{
Pengembangan lembar kegiatan peserta didik berbasis Thinking Actively in Social Context (TASC) untuk meningkatkan kemampuan mencipta pada peserta didik SMA
}

\author{
Linda Titi Lestari \\ Program Studi Pendidikan Fisika, FKIP, Universitas Muhammadiyah Purworejo \\ Jl. KH. Ahmad Dahlan No. 3 Purworejo, Jawa Tengah \\ Surat-e: linda.titilestari@gmail.com
}

Eko Setyadi Kurniawan

Program Studi Pendidikan Fisika, FKIP, Universitas Muhammadiyah Purworejo

J1. KH. Ahmad Dahlan No. 3 Purworejo, Jawa Tengah

Surat-e: ekosetyadik@gmail.com

Siska Desy Fatmaryanti

Program Studi Pendidikan Fisika, FKIP, Universitas Muhammadiyah Purworejo Jl. KH. Ahmad Dahlan No. 3 Purworejo, Jawa Tengah

Surat-e: sd_fatmaryanti@yahoo.com

Telah dikembangkan LKPD berbasis Thinking Actively in Social Context (TASC) untuk mengetahui kelayakannya terhadap kemampuan mencipta peserta didik. Jenis penelitian pengembangan ini mengacu model ADDIE. Penelitian dilaksanakan di SMA Negeri 1 Purworejo. Hasil analisis data yaitu: (1) Validasi LKPD berbasis TASC dari tiga validator mendapatkan 3,45 dengan kategori cukup baik dan uji reliabilitas sebesar $81 \%$ dengan kategori reliabel. (2) Tanggapan peserta didik terhadap LKPD berbasis TASC ada uji coba terbatas dalam kategori sangat baik dengan persentase $84 \%$ dan uji coba luas $78 \%$ dengan kategori baik. (3) Peningkatan kemampuan mencipta pada peserta didik tinggi, hal ini ditunjukkan dari besarnya nilai normal gain 0,70 . Berdasar data di atas, LKPD berbasis TASC dapat digunakan sebagai alternatif bahan ajar Fisika di SMA.

It has been developed based on Thinking Actively in Social Context (TASC) LKPD to determine the feasibility of students' ability to create. This type of development research refers to the ADDIE model. The study was carried out at 1 Public High School Purworejo. The results of data analysis are: (1) Validation of TASC-based LKPD from three validators to get 3.45 with a fairly good category and a reliability test of $81 \%$ with a reliable category. (2) The response of students to the TASC-based LKPD is that there are very good limited trials with a percentage of $84 \%$ and a broad trial of $78 \%$ with good categories. (3) Increasing the ability to create in high students, this is indicated by the magnitude of the normal value of gain of 0.70 . Based on the data above, TASC-based LKPDs that are feasible are can used as an alternative teaching material for highschool Physics learning.

Kata kunci: Lembar Kegiatan Peserta Didik, Thinking Actively in Social Context (TASC), Kemampuan Mencipta

\section{Pendahuluan}

Kualitas pembelajaran dapat dilihat dari kurikulum yang dikembangkan oleh pemerintah. Kurikulum merupakan pedoman yang yang disusun dan digunakan guna mencapai tujuan pembelajaran [1]. Pada tahun 2013, pemerintah mengembangkan kurikulum yang disebut dengan kurikulum 2013 yang menekankan pendekatan scientific atau pendekatan ilmiah. Proses pembelajaran dilaksanakan secara kontekstual berdasar fakta atau fenomena dalam kehidupan sehari-hari yang dapat dilogika. Peserta didik diharapkan memiliki kemampuan berpikir kritis, analitis, dan mengidentifikasi suatu permasalahan, memecahkan masalah, dan menerapkannya dalam kehidupan sehari-hari.

Pada kenyataannya, pembelajaran yang dilaksanakan menitikberatkan pada kemampuan mengingat, memahami, dan menerapkan. Peserta didik belum terbiasa berpikir kritis dan kreatif, padahal kemampuan berpikir ini sangat penting karena dalam kehidupan sehari-hari [2]. Setiap peserta didik dihadapkan pada 
berbagai masalah yang harus dipecahkan dan menuntut pemikiran kreatif untuk menemukan solusi dari permasalahan yang dihadapi.

Kegiatan pembelajaran yang berpusat pada guru menyebabkan peserta didik cenderung pasif, akibatnya kemampuan berpikir tingkat tinggi peserta didik tidak terlatih dengan baik, karena tidak terlatih untuk menemukan solusin permasalahan yang dihadapinya secara mandiri [3].

Menurut taksonomi Bloom, kemampuan berpikir tingkat tinggi mencakup tiga aspek ranah kognitif salah satunya adalah kemampuan mencipta (create) [12]. Kemampuan mencipta termasuk dalam kategori kreativitas di mana kemampuan tersebut bertujuan untuk menciptakan pola baru yang sesuai dengan kondisi/ situasi tertentu dan juga kemampuan mengatasi masalah dengan mengeksplorasi kreativitas diri. Kemamapuan berpikir kreatif peserta didik belum diasah dan dikembangkan secara optimal oleh guru, karena guru memiliki keterbatasan waktu untuk menerapkan kegiatan pembelajaran yang bervariasi [4]. Idealnya kemampuan mencipta berada pada kisaran $80 \%$ [5]. Rendahnya kemampuan mencipta peserta didik merupakan permasalahan besar yang harus segera diatasi.

Berdasarkan wawancara kepada Ibu Retno Wijayanti selaku guru mata pelajaran Fisika di SMA N 1 Purworejo diperoleh informasi bahwa proses pembelajaran fisika di dalam kelas dilakukan dengan metode diskusi dan sesekali melakukan demonstrasi. Kendala yang dihadapi saat proses pembelajaran fisika yaitu tidak semua peserta didik berperan aktif dalam diskusi. Penggunaan bahan ajar yang tidak bervariasi diduga menjadi salah satu penyebab peserta didik tidak berperan aktif dalam diskusi. Pengamatan yang dilakukan oleh peneliti di SMA Negeri 1 Purworejo diketahui bahwa guru masih menggunakan metode konvensional (ceramah) berbabtuan materi presentasi. Peserta didik hanya menerima dan mempelajari materi pelajaran yang diberikan oleh guru. Bahan ajar yang digunakan belum bervariasi, hanya berupa modul dan buku cetak yang belum mengarahkan peserta didik dalam menemukan masalah, merumuskan hipotesis, mengumpulkan data, menguji hipotesis, menyimpulkan hasil, serta menciptakan suatu produk. Hal tersebut disebabkan karakteristik bahan ajar yang digunakan belum dapat menggali keaktifaan dan kreatifitas peserta didik.

Berdasarkan kebutuhan terhadap bahan ajar yang dapat menekankan kemampuan mencipta dan aktivitas berpikir melalui konteks sosial, maka dilakukan penelitian dan pengembangan LKDP berbasis TASC guna meningkatkan kemampuan mencipta peserta didik dalam pembelajaran Fisika SMA.

\section{Kajian Pustaka}

\section{Lembar Kegiatan Peserta Didik}

Lembar Kegiatan Peserta Didik (LKPD) merupakan salah satu bahan ajar cetak yang digunakan oleh guru untuk menunjang kegiatan pembelajarannya. Pustaka [6] mengatakan bahwa LKPD dapat berupa tugas teori maupun praktek yang disusun secara sistematis. Lembar kegiatan peserta didik berbeda dengan lembar kerja peserta didik. Lembar kerja peserta didik yaitu bahan ajar yang dikemas untuk pembelajaran mandiri [7]. Lembar kerja peserta didik merupakan susunan tugas dalam pembelajaran yang digunakan sebagai petunjuk bagi peserta didik dalam menyelesaikan masalah [8].

LKPD dapat dikembangkan oleh guru secara mandiri sebagai pendukung kegiatan pembelajaran berisi ringkasan materi, soal-soal, dan panduan tugas/ praktikum yang harus dikerjakan peserta didik. Penyusunannya harus disesuaikan dengan KI dan KD yang harus dicapai, serta sesuai dengan bahan acuan utama. Pustaka [9] mengatakan bahwa keberadaan LKPD berpengaruh cukup besar dalam proses pembelajaran, sehingga penyusunan LKPD harus memenuhi berbagai persyaratan yaitu syarat didaktik (penggunaan LKPD yang bersifat universal), syarat konstruksi (penggunaan bahasa, susunan kalimat, kosa kata, tingkat kesukaran dan kejelasan), dan syarat teknik (penyajian LKPD).

Pengembangan LKPD bertujuan untuk mengembangkan lembar kegiatan peserta didik baru atau menyempurnakan yang telah ada. Pada saat mendesain LKPD perlu memperhatikan beberapa faktor, yaitu tingkat kemampuan membaca peserta didik dan pengetahuan peserta didik. Peserta didik diharapkan mampu belajar secara mandiri dengan LKPD yang telah didesain oleh guru. Guru menjadi fasilitator ketika peserta didik berperan secara aktif dalam mempelajari materi. Menghasilkan LKPD yang inovatif dan kreatif perlu memperhatikan langkah-langkah penyusunan LKPD yang baik. Langkah-langkah penyusunan LKPD, yaitu: (a) melakukan analisis kurikulum; (b) menyusun peta kebutuhan LKPD; (c) menentukan judul LKPD; dan (d) menulis LKPD [6].

\section{Thinking Actively in Social Context (TASC)}

Kerangka pembelajaran TASC yang dikembangkan oleh Belle Wallace merupakan kerangka yang mengajarkan peserta didik berpikir, menyelesaikan masalah, dan kreativitas. TASC menggabungkan berbagai strategi dan keterampilan guna memperoleh pemikiran baru dalam pembelajaran berdasarkan teori psikologi kognif. TSAC menekankan pada kemampuan berpikir dan pemecahan masalah, dengan elemen kemampuan berpikir (thinking), partisipasi peserta didik dalam pembelajaran (actively), kerja sama sosial (social collaboration), dan pembelajaran yang relevan dengan pengalaman peserta didik (context) [10].

Keunggulan TASC memungkinkan pengembangan kompetensi peserta didik dalam menyelesaikan masalah yang dihadapi baik di sekolah maupun di luar sekolah dalam situasi kehidupan nyata. Tahapan TASC menurut Wallace meliputi: 1) mengorganisasi pengetahuan berdasarkan permasalahan); 2) mengidentifikasi gagasan; 4) mengambil keputusan; 5) penerapan gagasan pada proses penyelesaian masalah; 6) mengkomunikasikan 
hasil penyelesaian masalah; dan 8) merefleksikan hasil belajar yang diperoleh dari proses penyelesaian masalah [11].

\section{Kemampuan Mencipta}

Kemampuan berpikir merupakan ranah kognitif dalam taksonomi Bloom yang terdiri dari berbagai tingkatan. Pada tahun 2002 Krathwohl [12] menulis "A Revision Of Bloom's Taxonomy: An Overview - Theory Into Practice" dengan melakukan revisi mendasar atas klasifikasi kognitif yang pernah dikemukakan oleh Bloom. Revisi yang dilakukan oleh Krathwohl terdiri atas dua dimensi yaitu proses dan isi/jenis. Dimensi proses meliputi: mengingat (remember), memahami (understand), menerapkan (apply), menganalisis (analyze), menilai (evaluate), dan berkreasi (create). Pada dimensi isinya terdiri atas pengetahuan faktual (factual knowledge), pengetahuan konseptual (conceptual knowledge), pengetahuan prosedural (procedural knowledge), dan pengetahuan metakognisi (metacognitive knowledge).

Pustaka [12] A revision of Bloom's Taxonomy: an Overview - Theory Into Practice memaparkan bahwa indikator untuk mengukur kemampuan berpikir tingkat tinggi meliputi: 1) kemampuan menganalisis (to analyze); 2) kemampuan mengevaluasi (to evaluate); 3) kemampuan mencipta (to create). Mencipta merupakan proses penyusunan elemen-elemen menjadi sebuah keseluruhan yang koheren datau fungsional. Tujuan pendidikan mencipta yaitu peserta didik dapat membuat produk baru dengan mereorganisasi sejumlah elemen atau bagian sehingga menjadi sesuatu pola atau struktur yang tidak pernah ada sebelumnya [13]. Produk yang dihasilkan merupakan produk yang dapat digunakan sebagai bahan belajar mandiri peserta didik. Tujuan dalam kemampuan mencipta mengutamakan kemampuan peserta didik dalam menyintesiskan sesuatu menjadi keseluruhan, bukan orisinilitas atau kekhasan. Indikator kemampuan mencipta menurut Anderson dan Krathwohl [ 12] meliputi: (a) merumuskan (membuat hipotesis); (b) merencanakan (mendesain); (c) memproduksi (mengkontruksi). Dimensi kemampuan mencipta disajikan pada Tabel 1.

Tabel 1. Dimensi Proses Kognitif Kemampuan Mencipta

\begin{tabular}{cccl}
\hline No & $\begin{array}{c}\text { Proses } \\
\text { Kognitif }\end{array}$ & \multicolumn{1}{c}{ Istilah } & \multicolumn{1}{c}{ Definisi } \\
\hline 1 & Merumuskan & $\begin{array}{l}\text { Membuat } \\
\text { hipotesis }\end{array}$ & $\begin{array}{l}\text { Membuat hipotesis } \\
\text { berdasarkan } \\
\text { kriteria. } \\
\text { Merencanakan } \\
\text { prosedur untuk } \\
\text { menyelesaikan } \\
\text { suatu tugas. } \\
\text { Menciptakan suatu } \\
\text { produk. }\end{array}$ \\
\hline
\end{tabular}

Berdasarkan tinjauan pustaka yang telah dipaparkan, dalam penelitian yang dilakukan memiliki nilai kebaruan, antara lain: (1) LKPD yang dikembangkan adalah LKPD fisika berbasis TASC, (2) LKPD yang dikembangkan bertujuan untuk meningkatkan kemampuan berpikir tingkat tinggi pada peserta didik dalam mencipta.

\section{Metode Penelitian}

Desain penelitian yang digunakan adalah desain kuasi eksperimen dengan jenis penelitian pengembangan. Produk yang dikembangkan dalam penelitian ini adalah lembar kegiatan peserta didik berbasis TASC. Untuk meningkatkan kemampuan mencipta pada peserta didik dalam pembelajaran Fisika di SMA digunakan instrumen observasi dan tes hasil belajar.

Desain penelitian pengembangan LKPD dalam penelitian ini mengacu pada model ADDIE: (1) Analysis, berisi analisis kebutuhan untuk menyelesaikan masalah; (2) Design, menentukan kompetensi khusus, metode, bahan ajar dan strategi yang digunakan untuk proses pembelajaran. ; (3) Development, memproduksi program dan bahan ajar yang akan digunakan dalam program pembelajaran. Pengembangan LKPD dilaksanakan di Universitas Muhammadiyah Purworejo.; (4) Implementation, melaksanakan program pembelajaran dengan menerapkan desain atau spesifikasi pembelajaran. LKPD yang telah dikembangkan diujicobakan di kelas $\mathrm{X}$ MIPA 1 dan 2. Pada uji coba terbatas jumlah peserta didik yang diberi perlakuan sebanyak 6 orang, sedangkan pada uji coba luas atau tahap penerapan berjumlah 30 peserta didik.; (5) Evaluation, pada tahap ini seorang guru melakukan evaluasi program pembelajaran dan evaluasi hasil belajar. Hasil evaluasi dari pengembangan LKPD berupa perbaikan tahap akhir, sedangkan evaluasi hasil pembelajaran dilakukan tes kognitif terhadap peserta didik [14].

Sebagai tempat penelitian adalah SMA Negeri 1 Purworejo pada semester genap tahun pelajaran 2017/2018 bulan Januari 2018 hingga Agustus 2018. Instrumen yang digunakan dalam penelitian ini yaitu (1) lembar wawancara; (2) lembar observasi; (3) lembar validasi LKPD; (4) lembar respon peserta didik terhadap LKPD; (5) lembar keterlaksanaan pembelajaran; (6) soal pra tes dan pos tes. Teknik analisis data dilakukan dengan cara sebagai berikut.

\section{Analisis LKPD}

Analisis LKPD dilakukan menggunakan uji validitas dan uji reliabilitas. Uji validitas diperlukan untuk mengukur validitas LKPD untuk digunakan, yang dapat dihitung menggunakan persamaan (1).

$$
\text { persentase }(\%)=\frac{\sum f m}{\sum f a} \times 100 \%
$$

Hasil perhitungan persamaan (1) kemudian diubah ke dalam bentuk skor dengan rentang $1-4$, sehingga tingkat kelayakan instrumen dapat diketahui dengan persamaan (2) [15]. 


$$
\text { Nilai }=\text { persentase } \times \text { skor tertinggi }
$$

Langkah selanjutnya dikonversi ke dalam skala yang bersifat kualitatif dengan interpretasi tidak baik, kurang baik, cukup baik, dan baik.

Pengujian reliabilitas menggunakan Percentage Agreement (PA), yaitu persentase kesesuaian nilai antara penilai pertama dan kedua terhadap instrumen. PA dapat ditentukan dengan persamaan (3).

$$
P A=\left(1-\frac{A-B}{A+B}\right) \times 100 \%
$$

A dan B merupakan besar nilai yang diberikan penilai pertama dan kedua dengan $\mathrm{A}>\mathrm{B}$. Instrumen dapat dikatakan reliabel apabila nilai $\mathrm{PA} \geq 75 \%$ [15].

\section{Analisis Data Angket Respon Peserta Didik Terhadap LKPD}

Data yang telah diperoleh dihitung kemudian disajikan secara deskripsi persentase. Penyajian deskripsi persentase melalui tabel kriteria analisis data angket respon peserta didik terhadap LKPD berbasis TASC yang berisi tentang hal-hal yang diukur. Perhitungan data angket respon peserta didik dilakukan dengan menggunakan persamaan (4).

$$
N P=\frac{R}{S M} \times 100 \%
$$

Hasil presentase ini diubah ke dalam bentuk kriteria analisis sesuai dengan acuan Tabel 2.

Tabel 2. Kriteria Analisis Data Angket Respon Peserta Didik Terhadap LKPD Berbasis TASC

\begin{tabular}{cl}
\hline Tingkat Persentase (\%) & \multicolumn{1}{c}{ Keterangan } \\
\hline $86 \%-100 \%$ & Sangat baik \\
$76 \%-85 \%$ & Baik \\
$60 \%-75 \%$ & Cukup \\
$55 \%-59 \%$ & Kurang \\
$\leq 54 \%$ & Sangat kurang \\
\hline
\end{tabular}

\section{Analisis Data Lembar Keterlaksanaan Pembelajaran}

Data lembar keterlaksanaan pembelajaran dihitung menggunakan persamaan (3). Hasil persentase ini diubah ke dalam bentuk kriteria analisis data lembar keterlaksanaan pembelajaran dengan skala lima.

\section{Analisis Data Tes Kemampuan Mencipta}

Peningkatan kemampuan mencipta pada peserta didik dapat diketahui melalui observas dan tes hasil belajar sebelum dan setelah menggunakan bahan ajar yang dikembangkan. Peningkatan dapat diketahui menggunakan normalized gain (N-Gain) yang dicari menggunakan persamaan (5).

$$
g=\frac{S_{f}-S_{i}}{100-S_{i}}
$$

Hasil dari perhitungan $\mathrm{N}$-gain kemudian dikonversikan ke dalam klasifikasi normalized [16] dengan kriteria pada rendah, sedang, dan tinggi. Berdasarkan hasil Normalized Gain yang diperoleh, selanjutnya dapat dilihat apakah kemampuan peserta didik dalam mencipta dapat meningkat dengan adanya LKPD berbasis TASC.

\section{Hasil Penelitian dan Pembahasan}

Berdasarkan hasil penelitian dan pengembangan diperoleh data-data sesuai tahapan ADDIE yang dijelaskan sebagai berikut.

\section{Analysis (Analisis)}

Telah dilakukan analisis, yaitu analisis kebutuhan (need assesment) dan analisis konten. Analisis kebutuhan dilakukan dengan cara pengamatan, sehingga diketahui proses pembelajaran yang selama ini dilakukan masih didominasi dengan metode konvensional dan diskusi kelas, yang mana metode ini membuat sebagian peserta didik merasa bosan di dalam kelas. Bahan ajar yang digunakan dalam pembelajaran tidak bervariasi, karena hanya menggunakan modul. Modul tersebut tidak dapat mengukur kemampuan mencipta peserta didik karena masih didominasi oleh soal kognitif tingkat rendah dan belum menggunakan rubrik khusus untuk menilai kemampuan tersebut. Pada analisis konten dilakukan wawancara untuk mengetahui konten yang perlu dimasukkan ke dalam LKPD yang dikembangkan dengan materi Gerak Harmonis Sederhana yang disesuaikan kebutuhan peserta didik di sekolah.

Berdasarkan analisis yang telah dilakukan, dibutuhkan bahan ajar yang dapat meningkatkan kemampuan mencipta peserta didik yang diwujudkan dalam bentuk LKPD berbasis TASC.

\section{Design (Perancangan)}

Draf LKPD yang dikembangkan berupa bahan ajar cetak yang diterapkan menggunakan basis TASC. Darf LKPD disusun setelah melakukan analisis pada materi pembelajaran yaitu gerak harmonis sederhana. Darf LKPD berisi kegiatan peserta didik selama proses pembelajaran pada materi gerak harmonis sederhana. Draf LKPD yang dikembangkan memuat tiga lembar kegiatan yang disesuaikan dengan tahapan TASC.

\section{Development (Pengembangan)}

Darf LKPD kemudian diwujudkan ke dalam bentuk media cetak untuk divalidasi oleh ahli dan guru fisika. 
Langkah selanjutnya, draf LKPD dianalisis tingkat kevalidannya, dilakukan uji coba terbatas. Pada tahap ini, dilakukan juga validasi instrumen tes kemampuan mencipta oleh ahli.

Hasil penilaian validasi LKPD berbasis TASC oleh ahli pada aspek keterbacaan LKPD diperoleh skor 13 sehingga memperoleh persentase $81,25 \%$ dan rerata skor 3,25 dengan kategori cukup baik. Aspek kebahasaan LKPD diperoleh skor 20 sehingga memperoleh persentase 83,33\% dan rerata skor 3,33 dengan kategori cukup baik. Aspek desain dan tampilan LKPD diperoleh skor 32 sehingga memperoleh persentase $80 \%$ dan rerata skor 3,20 dengan kategori cukup baik. Aspek kelayakan isi diperoleh skor 69 sehingga memperoleh persentase $86,25 \%$ dan rerata skor 3,45 dengan kategori cukup baik. Keseluruhan aspek mendapatkan nilai 13,23 sehingga reratanya 3,30 dengan kategori cukup baik. Gambar 1 menyajikan diagram hasil uji kelayakan LKPD Berbasis TASC oleh ahli.

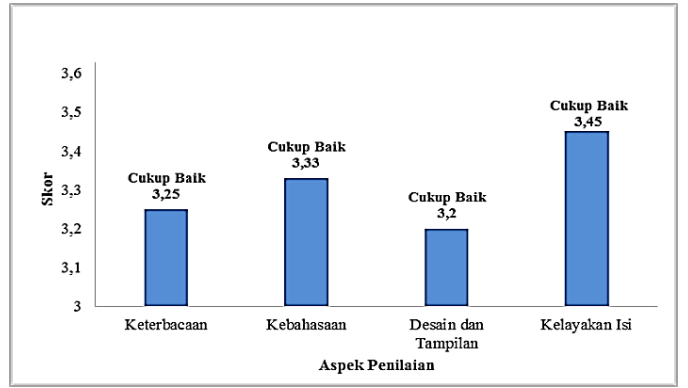

Gambar 1. Hasil Uji Kelayakan LKPD Berbasis TASC oleh Ahli

Penilaian oleh guru fisika pada aspek keterbacaan memperoleh skor 7 sehingga diperoleh persentase $87,5 \%$ dan skor 3,50 dengan kategori cukup baik. Aspek kebahasaan memperoleh skor 12 sehingga diperoleh persentase $100 \%$ dan skor 4,00 dengan kategori baik. Aspek desain dan tampilan memperoleh skor 17 sehingga diperoleh persentase $85 \%$ dan skor 3,40 dengan kategori cukup baik. Aspek kelayakan isi memperoleh skor 34 sehingga diperoleh persentase $85 \%$ dan skor 3,40 dengan kategori cukup baik. Keseluruhan aspek mendapatkan nilai 14,40 sehingga rerata skornya 3,60 dengan kategori baik. Hasil uji kelayakan LKPD berbasis TASC oleh Guru Fisika tersaji pada Gambar 2.

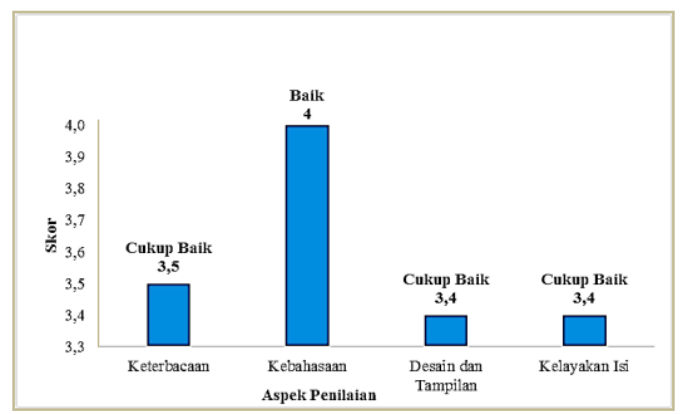

Gambar 2. Hasil Kelayakan LKPD Berbasis TSAC oleh Guru Fisika
Respon peserta didik menggunakan LKPD berbasis TASC meliputi 3 aspek yaitu penerapan LKPD, penerapan basis TASC, dan penerapan kemampuan mencipta. Pada ujicoba terbatas, respon peserta didik pada aspek penerapan LKPD mendapatkan persentase 84\% dengan klasifikasi baik. Aspek penerapan basis TASC mendapatkan persentase $89 \%$ dengan klasifikasi sangat baik. Aspek penerapan kemampuan mencipta mendapatkan persentase $84 \%$ dengan klasifikasi baik. Keseluruhan aspek mendapatkan persentase $85 \%$, dapat disimpulkan bahwa tanggapan peserta didik menggunakan LKPD berbasis TASC adalah baik. Diagram respon peserta didik terhadap LKPD berbasis TASC pada uji coba terbatas tersaji dalam Gambar 3.

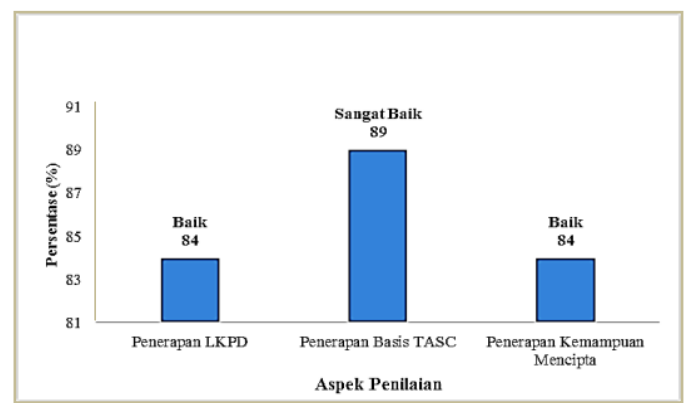

Gambar 3. Hasil tanggapan peserta didik terhadap LKPD berbasis TASC pada uji coba terbatas

Penilaian validasi soal tes kemampuan mencipta dilakukan oleh ahli dan guru fisika. Penilaian oleh ahli pada aspek cakupan materi diperoleh skor 4 sehingga memperoleh persentase $100 \%$ dengan nilai 4 yang dikategorikan baik. Aspek kemampuan mencipta diperoleh skor 14 sehingga memperoleh persentase $70 \%$ dengan nilai 2,8 yang dikategorikan cukup baik. Aspek keterbacaan diperoleh skor 7 memperoleh persentase $88 \%$ dengan nilai 3,5 yang dikategorikan cukup baik. Aspek kebahasaan diperoleh skor 17 sehingga memperoleh persentase $85 \%$ dengan nilai 3,4 yang dikategorikan cukup baik. Keseluruhan aspek mendapatkan nilai 13,7 reratanya 3,4 dengan kategori cukup baik. Hasil penilaian tersebut disajikan pada Gambar 4.

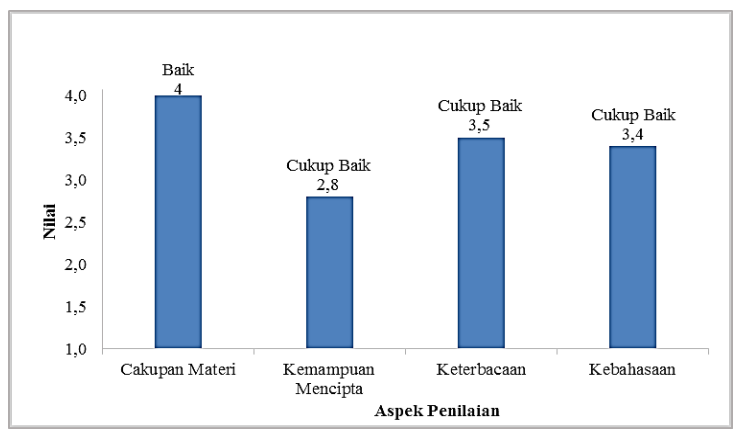

Gambar 4. Hasil Kelayakan Soal Tes Kemampuan Mencipta oleh Ahli

Penilaian oleh Guru fisika pada aspek cakupan materi diperoleh skor 4 memperoleh persentase $100 \%$ dengan 
nilai 4 yang masuk dalam kategori baik. Aspek kemampuan mencipta diperoleh skor 18 sehingga memperoleh persentase $90 \%$ dengan nilai 3,6 yang dikategorikan baik. Aspek keterbacaan diperoleh skor 8 sehingga mendapat persentase $100 \%$ dengan nilai 4 yang dikategorikan baik. Aspek kebahasaan diperoleh nilai 20 sehingga memperoleh persentase $100 \%$ dengan nilai 4 yang dikategorikan baik. Keseluruhan aspek mendapat nilai 15,6 sehingga reratanya 3,9 dengan kategori baik. Hasil penilaian tersebut disajikan pada Gambar 5.

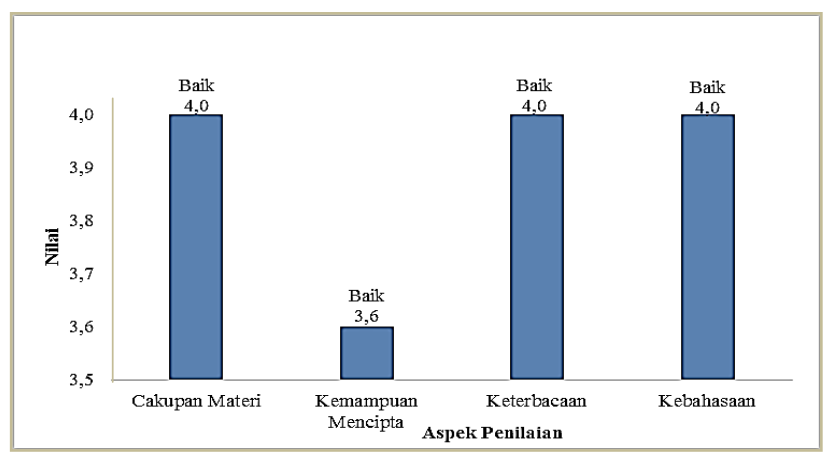

Gambar 5. Hasil Kelayakan Soal Tes Kemampuan Mencipta oleh Guru Fisika

\section{Implementation (Penerapan)}

Pada tahap penerapan, peneliti melakukan uji coba luas LKPD berbasis TASC yang telah divalidasi dengan menerapkan pada satu kelas. Pada tahap bertujuan untuk mengetahui kemampuan mencipta pada peserta didik, yang diketahui melalui hasil angket dan hasil tes hasil belajar.

Kemampuan mencipta peserta didik dapat diamati pada aspek yang sesuai dengan indikator kemampuan mencipta. Pada aspek 1, terjadi pengurangan jumlah pada item kategori rendah yaitu 25 menjadi 9, pada kategori tinggi yang meningkat dari 5 menjadi 21. Item kategori pada asepek 2 menurun dari 25 menjadi 10, dan kategori tinggi meningkat dari 5 bertambah menjadi 20. Pada aspek 3, penurunan juga terjadi dari 28 menjadi 11, dan item kategori tinggi yang awalnya berjumlah 2 bertambah menjadi 19. Berdasar data tersebut, pada kondisi awal diperoleh rerata jumlah peserta didik yang memiliki kemampuan mencipta rendah ada 26 dan 4 berkemampuan mencipta tinggi. Pada kondisi akhir, rerata jumlah peserta didik yang memiliki kemampuan mencipta rendah ada 11 dan 19 berkemampuan mencipta tinggi. Diagram observasi kemampuan mencipta tersaji dalam Gambar 6.

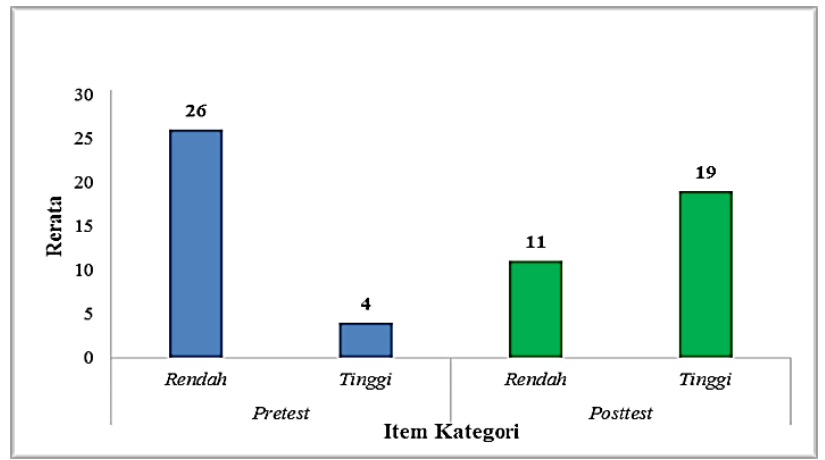

Gambar 6. Hasil Observasi Kemampuan Mencipta

Kemampuan mencipta pada peserta didik ditinjau melalui tes kognitif dengan melakukan pra tes dan pos tes. Berdasarkan hasil pra tes memperoleh skor rerata sebesar 25,77 dan pos tes memiliki skor rerata 77,37. Persentase ketuntasan hasil test kemampuan berpikir tingkat tinggi pada aspek mencipta dinyatakan tuntas memperoleh kriteria gain 0,70 dengan kategori tinggi. Diagram hasil kemampuan mencipta pada peserta didik (pre tes dan pos tes) disajikan dalam Gambar 7.

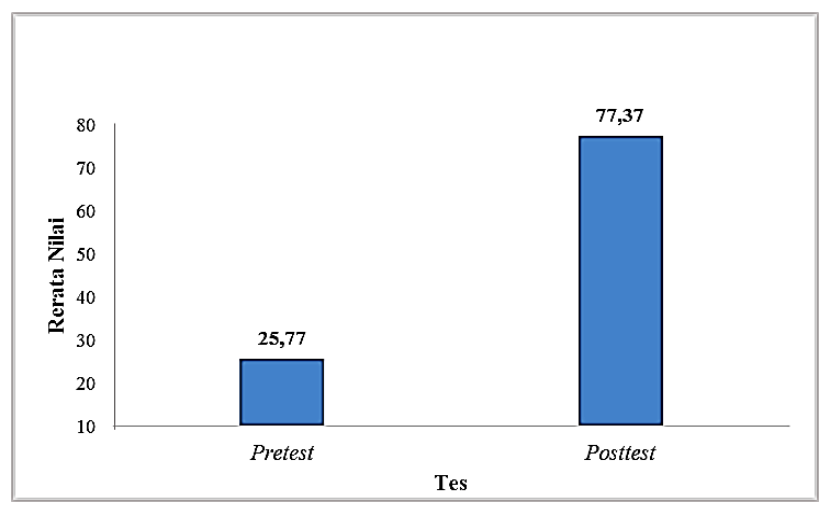

Gambar 7. Hasil Tes Kemampuan Mencipta

Guna mengetahui respon peserta didik terhadap LKPD berbasis TASC digunakan angket yang dibagikan kepada peserta didik setelah proses pembelajaran berantuan LKPD selesai dilaksanakan. Pada aspek penerapan LKPD mendapatkan persentase $77 \%$ dengan klasifikasi baik. Aspek penerapan basis TASC mendapatkan persentase $81 \%$ dengan klasifikasi baik. Aspek penerapan kemampuan mencipta mendapatkan persentase $78 \%$ dengan klasifikasi baik. Keseluruhan aspek mendapatkan persentase $78 \%$, dapat disimpulkan bahwa respon peserta didik menggunakan LKPD berbasis TASC adalah baik. Gambar 8 menampilkan respon peserta didik setelah menggunakan LKPD berbasis TASC. 
Pengembangan lembar kegiatan peserta didik berbasis Thinking Actively in Social Context (TASC) untuk meningkatkan kemampuan mencipta pada peserta didik SMA

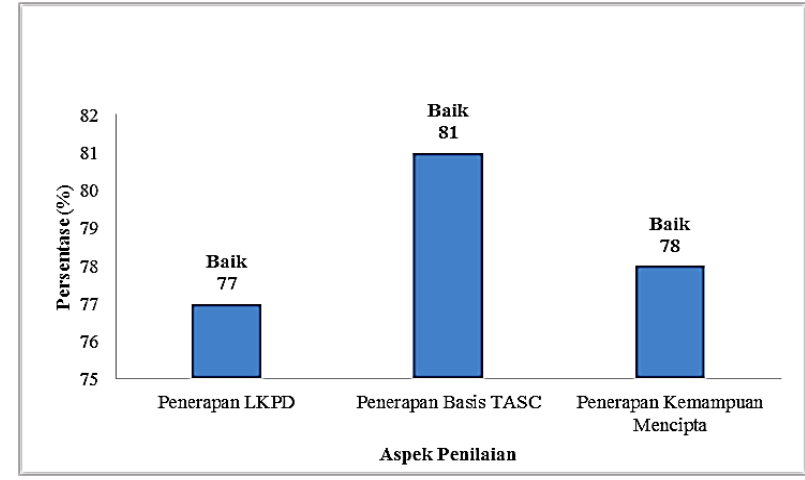

Gambar 8. Respon Peserta Didik Terhadap LKPD berbasis TASC.

Keterlaksanaan pembelajaran menggunakan LKPD berbasis Thinking Actively in Social Context dievaluasi oleh 2 observer. Observer memberikan nilai pada lembar observasi yang telah disediakan. Tabel 3 menyajikan data hasil observasi keterlaksanaan pembelajaran oleh 2 observer dalam dua kali pertemuan.

Tabel 3. Hasil Pengamatan Keterlaksanaan Pembelajaran

\begin{tabular}{ccccccc}
\hline \multirow{2}{*}{ No } & \multirow{2}{*}{ Aspek } & \multicolumn{5}{c}{ Pertemuan } \\
& Keterlaksanaan & \multicolumn{1}{c}{ I } & \multicolumn{1}{c}{ II } \\
& & $\mathbf{1}$ & $\mathbf{2}$ & $\mathbf{1}$ & $\mathbf{2}$ \\
\hline 1 & Pendahuluan & 7 & 8 & 8 & 8 \\
2 & Kegiatan Inti & 26 & 25 & 27 & 25 \\
3 & Penutup & 4 & 4 & 4 & 4 \\
\hline & Jumlah & 37 & 37 & 39 & 37 \\
\hline & Persentase (\%) & \multicolumn{2}{c}{100} & \multicolumn{3}{c}{97,4} \\
\hline & Kategori & \multicolumn{2}{c}{ Sangat baik } & \multicolumn{3}{c}{ Sangat baik } \\
\hline
\end{tabular}

\section{Evaluate (Evaluasi)}

Pada tahap evaluasi dilakukan analisis LKPD yang dikembangkan pada saat implementation, yaitu berdasarkan hasil implementation LKPD berbasis TASC ini layak dijadikan sebagai alternatif bahan ajar. LKPD ini ternyata dapat meningkatkan kemampuan peserta didik dalam mencipta.

\section{Kesimpulan}

Berdasarkan analisis data di atas, LKPD berbasis TASC yang dikembangkan layak digunakan, Tanggapan peserta didik terhadap LKPD berbasis TASC adalah baik. Peningkatan kemampuan mencipta pada peserta didik termasuk dalam kategori tinggi dilihat dari nilai prates dan postes.

\section{Kepustakaan}

[1] Yurni, S. dan Bakti, H.E., Pengembangan Kurikulum Di Sekolah Dalam Upaya Meningkatkan Mutu Pendidikan, Laporan Hasil Penelitian Universitas Muhammadiyah Palembang Sumatera Selatan, Program Studi Administrasi Pendidikan, 2016.

[2] K. Nisa, "Pengaruh pendekatan open-ended terhadap kemampuan berpikir kreatif siswa pada materi listrik dinamis kelas X Di
SMAN I Gondang Tulungagung", Inovasi Pendidikan Fisika vol. 2, no. 3, pp. 143-146, 2013.

[3] L. S. Handriani, A. Harjono, \& A. Doyan, "Pengaruh model pembelajaran inkuiri terstruktur dengan pendekatan saintifik terhadap kemampuan berpikir kritis dan hasil belajar fisika siswa", Jurnal Pendidikan Fisika dan Teknologi, vol. 1, no.3 , pp. 210-220, 2017.

[4] M. R. Primadi, S. Sarwanto, \& S. Suparmi, "Pengembangan modul fisika berbasis inkuiri terbimbing untuk meningkatkan kemampuan berpikir kreatif siswa pada materi listrik dinamis", Jurnal Riset dan Kajian Pendidikan Fisika, vol,5, no. 1, pp. 1-9, 2018 .

[5] S. Haryandi, "Pengembangan model pembelajaran tasc untuk meningkatkan kemampuan mencipta peserta didik dalam fisika", Prosiding: Seminar Nasional Fisika Dan Pendidikan Fisika, pp. 166-173, 2015.

[6] A. Prastowo, Panduan Kreatif Membuat Bahan Ajar Inovatif, Yogyakarta: DIVA Press, 2015.

[7] R. D. Fannie, \& R. Rohati, "Pengembangan lembar kerja siswa (lks) berbasis poe (predict, observe, explain) pada mater program linear kelas XII SMA", Sainmatika: Jurnal Sains dan Matematika Universitas Jambi, vol.8, no. 1, pp. 96-109, 2014.

[8] D. S. Damayanti, "Pengembangan lembar kerja siswa (lks) dengan pendekatan inkuiri terbimbing untuk mengoptimalkan kemampuan berpikir kritis peserta didik pada materi listrik dinamis SMA Negeri 3 Purworejo Kelas X Tahun Pelajaran 2012/2013", RADIASI: Jurnal Berkala Pendidikan Fisika, vol.3, no.1,pp. 58-62, 2013.

[9] E. Widjajanti, "Kualitas lembar kerja siswa", Pengabdian, 2008, [Online]. Tersedia: http://staff.uny.ac.id/system/files/pengabdian/endang-widjajantilfx-msdr/kualitas-lks.pdf [Diakses: 30 November 2017].

[10] I. Rosidi, "Uji kelayakan perangkat pembelajaran pengelolaan limbah dengan pendekatan TASC (thinking actively in social context)", Science Education Journal, vol.1,no. 1, pp. 7-18, Mei 2017.

[11] B. Wallace, "Thinking in context", Fifted Education International, 2012.

[12] D. R. Krathwohl," A revision of Bloom's taxonomy: an overview", Theory Into Practice. College of Education, The Ohio State University, vol. 41, no. 4, pp. 212-218 2002

[13] L. W. Anderson,. \& D. R. Krathwohl (Eds.), "Kerangka landasan untuk pembelajaran, pengajaran, dan asesmen", (Terjemahan Agung Prihantoro). Yogyakarta: Pustaka Pelajar, 2015.

[14] B. A. Pribadi, "Model desain sistem pembelajaran", Jakarta: Dian Rakyat, 2010.

[15] A. Prastiwi, "Pengembangan modul fisika berbasis masalah untuk meningkatkan high order thinking skills (HOTS) siswa SMA, Universitas Muhammadiyah Purworejo, 2016.

[16] Hake \& R. Richard, "Analyzing Change/Gain Scores", Dept of Physics. Indiana University. 1999. 